\title{
Interview
}

\section{Medical Cannabis} and Cannabinoids
Med Cannabis Cannabinoids 2018;1:5

DOI: $10.1159 / 000489141$
Published online: June 12, 2018

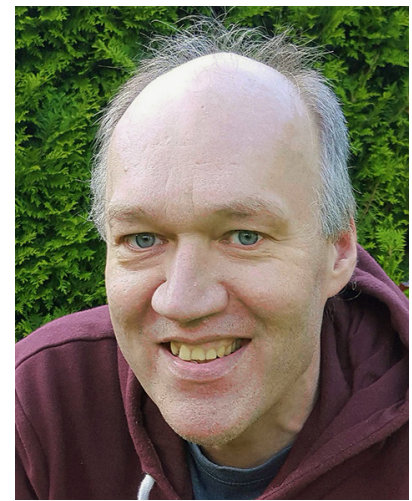

Franjo Grotenhermen, MD, born in 1957, academic studies of medicine at the University of Cologne.

Runs a medical practice mainly devoted to the medical use of cannabis and cannabinoids.

Founder and chairman of the German Association for Cannabis as Medicine (ACM); founder and executive director of the International Association for Cannabinoid Medicines (IACM).

Editor of the IACM Bulletin, published bi-weekly in several languages. Principal of the nova-Institute, based near Cologne, and author of many articles, books, and book chapters on the therapeutic potential, pharmacology, and toxicology of cannabinoids.

E-Mail franjo.grotenhermen@nova-institut.de
No molecule on earth has such a wide spectrum of action as THC, and the cannabis plant itself has been viewed as a form of "safe medicine" by many users for decades. Governments, regulators, and medical professions are, however, still struggling to agree how best to exploit the therapeutic potential of medical cannabis.

My view is that the people's health should be the prime consideration of any government that is adjudicating on the use of cannabis for medical purposes. The narcotics laws were established to protect people from the harmful effects of narcotics; they were not created to punish sick people seeking relief from illness. And governments should not hinder people from obtaining the help they require when sick. This argument has recently been effectively used in Germany, where medical cannabis has been available in pharmacies since 2017 and medical insurance companies are now obliged to cover its use under certain circumstances.

There is a debate in Germany at present as to what constitutes "good medicine" in this context. To some, cannabis-based pharmaceutical drugs (such as Sativex and Dronabinol) provide the way forward, and the use of the plant itself belongs in the Stone Age. To others, the cannabis plant is "God's pharmacy" and offers benefits that cannot be obtained from a product "synthesized" by a pharmaceutical manufacturer. To my mind, everything that helps patients in need is good, and I consequently believe that we should think in much broader terms.

All major pharma players are currently exploring ways of synthetically modulating the endocannabinoid system to increase the level of endocannabinoids in the case of illness and to hinder their degradation. They are also exploring nonpsychoactive synthetic compounds. At the same time, research into the cannabis plant itself will increase in years to come, for the phytocannabinoid THC has properties that cannot be replicated by the synthetic cannabinoids currently available.

The advances in the use of medical cannabis to treat conditions such as chronic pain, spasticity, and Tourette syndrome that we have witnessed since the 1970s have come about from medical practitioners listening to patients - not from laboratory experiments with mice. I hope that Medical Cannabis and Cannabinoids will inspire readers to listen to the evidence available and to contribute to the future research efforts that are so greatly needed.

\begin{tabular}{|c|c|}
\hline KARGER & $\begin{array}{l}\text { (c) } 2018 \text { The Author(s) } \\
\text { Published by S. Karger AG, Basel }\end{array}$ \\
\hline $\begin{array}{l}\text { E-Mail karger@karger.com } \\
\text { www.karger.com/mca }\end{array}$ & $\begin{array}{l}\text { This article is licensed under the Creative Commons Attribution- } \\
\text { NonCommercial-NoDerivatives } 4.0 \text { International License (CC BY- } \\
\text { NC-ND) (http://www.karger.com/Services/OpenAccessLicense). } \\
\text { Usage and distribution for commercial purposes as well as any dis- } \\
\text { tribution of modified material requires written permission. }\end{array}$ \\
\hline
\end{tabular}

